\title{
Learning Methods Tahfidz AI-Qur'an Leading Class Program in Madrasah Tsanawiyah Islamiyah Blingoh
}

\author{
Ummi Rohmawati ${ }^{1}$, Ashif Az Zafi ${ }^{2}$ \\ ${ }^{1}$ Institut Agama Islam Negeri Kudus, Indonesia \\ ${ }^{2}$ Institut Agama Islam Negeri Kudus, Indonesia \\ 1'rahmawatiumi123@gmail.com \\ 2ashifazzafi@iainkudus.ac.id
}

do) DOI: 10.37542/iq.v4i01.173

\begin{abstract}
Abstrak
Pendidikan agama Islam sangat penting bagi setiap individu yang beragama Islam. Setiap madrasah mengajarkan pendidikan agama Islam untuk menghasilkan lulusan yang baik dan berkualitas. Dalam menghafal al-Qur'an diperlukan metode yang tepat agar penghafal tidak hanya hafal tetapi mampu membaca ayat dengan makhroj yang benar. Penelitian dilakukan dengan metode penelitian lapangan melalui wawancara dengan guru Tahfidz Qur'an dan kepala Madrasah Tsanawiyah Islamiyah Blingoh. Penelitian ini bertujuan untuk mengetahui bagaimana proses pembelajaran, metode pembelajaran yang diterapkan, dan faktor-faktor yang mendukung dan menghambat siswa dalam melaksanakan proses pembelajaran Tahfidz. Hal ini terlihat dari perhatian dan upaya ustadz yang membimbing dan membimbing santri dalam menghafal Al-Qur'an. Dalam pembelajaran Tahfidz Qur'an ada hal yang harus diperhatikan yaitu mengatur niat untuk mencari keridhaan Allah SWT. Metode yang digunakan dalam pembelajaran Tahfidz Qur'an adalah Bin-Nadhar, talaqqi, tahfidz dan murojaah. Selama proses kegiatan Tahfidz, terdapat faktor pendukung bagi siswa dalam proses pembelajaran, seperti motivasi, persiapan diri yang matang, faktor usia, waktu, potensi daya ingat dan kecerdasan serta tempat yang nyaman untuk menghafal. Selain itu, hal tersebut merupakan faktor yang menghambat siswa dalam melaksanakan proses pembelajaran. Yakni, kurangnya motivasi diri untuk menghafal, kurangnya minat terhadap bakat, melakukan perbuatan yang mengarah pada perbuatan maksiat, dan kesehatan fisik yang menurun.
\end{abstract}

Kata Kunci: Metode, Pembelajaran, Tahfidz Qur'an 


\begin{abstract}
Islamic religious education is very important for every individual who is Muslim. Each madrasa teaches Islamic religious education to produce good and quality graduates. In memorizing al-Qur'an, a proper method is needed so that the memorizer is not only memorized but is able to recite verses with the correct machroj. The research was carried out by field research through interviews with the teachers of Tahfidz Qur'an and the principal of Madrasah Tsanawiyah Islamiyah Blingoh. The research aims to determine how the learning process, the learning methods applied, and the factors that support and hinder students in carrying out the Tahfidz learning process. This can be seen from the attention and efforts of the ustadz who guide and guide students in memorizing the Qur'an. In the learning Tahfidz Qur'an, there are things that must be considered, namely arranging the intention to seek the pleasure of Allah SWT. The methods used in the Tahfidz Qur'an learning are Bin-Nadhar, talaqqi, tahfidz and murojaah. During the process of Tahfidz activities, there are supporting factors for students in the learning process, such as motivation, careful self-preparation, age factors, timing, potential for memory and intelligence as well as a comfortable place to memorize. In addition, it is a factor that hinders students from carrying out the learning process. Namely, lack of self-motivation to memorize, lack of interest in talents, commit actions that lead to sinful acts, and decreased physical health.
\end{abstract}

Keywords: Method, Learning, Tahfidz Qur'an

\title{
Introduction
}

Al-Qur'an is the first source of law in Islamic law. The Koran is the holy book containing the words of Allah that was revealed to the Prophet Muhammad through the angel Jibril, which was taught to Muslims as a provision for guidance in living life in the world and in the hereafter. The authenticity of the Qur'an is maintained, unlike the previous books such as the Torah and the Bible. The Qur'an was conveyed to the Prophet Muhammad SAW and then accepted by the companions, after which it was conveyed to the next generation, to be preserved in the heart, read orally, and written in the Mushaf, then memorized by the Muslims to the next generation. Memorizing the Koran is a practice of worship that is highly recommended for Muslims who want to do it. Because those who want to memorize the Koran get their own guarantee from Allah SWT. Not only memorizing the Koran is guaranteed by Allah SWT, but a Muslim who wants to read and understand it and apply its contents in everyday life will get a special reward from Allah AWT. 
Al-Quran memorizers do not have to stay in a boarding school only as a place to memorize the Koran. Now many institutions have created the Tahfidz Qur'an program for students who are interested in memorizing the Koran which was developed through Madrasah Ibtidaiyah, Madrasah Tsanawiyah, and Madrasah Aliyah. The Tahfidz Qur'an program that has been implemented in school institutions has had a positive impact on the students who take it. This is evidence of the advancement of Islamic religious education in Indonesia. Every parent would want their children to be people who have good morals, so that they realize that the importance of learning Islam is to instill the Koran in the hearts of their children as a memorizer of the Koran through education that develops the Tahfidz Qur 'program. an. In memorizing the Koran, students must have experienced many difficulties. Like pronouncing verses that sometimes do not match the makharijul letters and tajwid because they are too focused on memorizing them, and are often confused when memorizing almost the same verse in different surahs.

Every child has different levels of memory from each other. When memorizing verses of the Koran, children will have a memory if they repeat the verses they have memorized. Some children will memorize when repeated 5 times, some will memorize when repeated 20 times, even 30 times. To overcome or minimize the difficulties experienced, appropriate methods are needed. God willing, the students will easily memorize the Koran. Allah says in QS alQamar verse 17 which means "And indeed, we have made it easy for us to warn the Koran (to remember and take lessons), so is there anyone who wants to take a lesson?". From this verse, it can be used as evidence that God's words are easy to memorize. This is a feature of the Qur'an that distinguishes it from other books. Reading the Qur'an and understanding its meaning is not easy. Never mind understanding its meaning which is so complete and perfect, and the discussion is deep, sometimes we still find it difficult to read it with clear letters. The Qur'an has a different side from the rest of Allah's books. Judging from the reading point of view, the Koran can be of value to our worship but it can also curse its readers (naudzubillah). This can happen both from our less steady intention and in our imperfect way of reading whether in terms of the use of tajwid which is not quite right or from the point of view of the letter's makharijul.

When reciting the Koran, it is not only limited to memorizing the letters and reading them, but it is also necessary to be able to distinguish the meanings of the letters. Reading with makharijul letters needs to be practiced, because when we pronounce it wrong, it will change the meaning or meaning. This has a very big effect, when we are good, fluent, correct, 
and fashih in reading the Koran, the results of our memorization may not be wrong. In memorizing the Qur'an, a proper method is needed. This is very important in order to achieve success in its implementation. Methods have a huge influence when we want to memorize the Qur'an. Because in the process of learning to memorize the Qur'an, without a method there is a possibility that it will not be successful in its implementation. The method is one of the components in the second lesson after the goal. Several components of learning, namely: objectives, methods, materials, media and evaluation.

Based on the results of research on the processes and methods of learning Tahfidz Qur'an which have been described above, the authors are encouraged to carry out research conducted in the superior class of Madrasah Tsanawiyah Islamiyah Blingoh. The research aims to determine the process of learning the Tahfidz Qur'an, the inhibiting and supporting factors in learning the Tahfidz Qur'an. Researchers are interested in researching at Madrasah Islamiyah Blingoh, because this madrasah is the only Madrasah Tsanawiyah in Blingoh Village that provides Tahfidz Qur'an for students who want to memorize the Qur'an. In its implementation, it has achieved $80 \%$ success.

\section{Discussion}

\section{Activities of the Tahfidz Qur'an Learning Process}

When we want to memorize the Al-Qur'an, the first thing we need to cultivate is a sincere intention to memorize the Qur'an because of Allah SWT, but this intention could be formed when we are used to memorizing the Qur'an. Because everything we do must be based on sincerity from Lillahi Ta'ala. Like the word of Allah in QS Al-Bayyinah verse five, it can be concluded that a person must be sincere both physically and spiritually in carrying out worship to Allah SWT, and be serious about improving oneself starting with arranging our intentions and goals. All our actions that are not based on intention will mean nothing with Allah SWT. When we want to memorize the Qur'an, we need to seek the pleasure of Allah SWT and happiness in the afterlife. Memorizing the Koran is a good deed and is an act of worship that is the most noble in the sight of Allah SWT. For this reason, as a candidate to memorize the Qur'an, he should have a feeling or intention only to seek the pleasure of Allah SWT, and to seek happiness in the hereafter. And not owning or avoiding riya 'actions by wanting others to know our abilities as memorizers of the Qur'an and so on. In this case, 
Muslims can be motivated to seriously try to become Ahlul Qur'an, because the Ahlul Qur'an is the Expert of Allah and is among the best of humans.

Carrying out the learning process is of course done with the main role that is a teacher. Because a teacher has a very important role in educating students in providing direction and material to be taught during the learning process. In the process of learning the Tahfidz Qur'an, things that need to be considered are not only memorizing it, but also from a reading perspective. We can see this from the way we read it with good and correct letter makharijul and reading based on recitation.

1) Read and memorize the Koran by understanding the Makharijul Letters. The meaning of the word Makhraj is a place of exit. So, the letter makharijul can be interpreted as the layout of the Hijaiyyah letter out of the mouth. There are 17 places where Makharijul Letters comes out which are divided into 5 places, namely:

a) Al-Jauf which means mouth opening and

b) Al-Halq's throat which means throat

c) Al-Lisan Which means

d) Ash-Shafatan's tongue which means the two lips of

e) Al-Khaisyuum which means the base of the nose.

2) Before reading and memorizing the Al-Quran, you should first study the knowledge of Tajweed.

Tajwid is a masdar of "Jawwad-ufawwidu-tajwid" which means to improve the reading. Based on the science of tajweed, tajwid is smoothing the reading of the Qur'anic sentences without haste, orderly, slowly, and lightly when reading them and according to the principles of recitation. The law of studying recitation to read and understand the Qur'an is fardhu kifayah. Fardu kifayah, that is, if one of a group or community of someone has done or implemented it, the obligation to carry out for the other has been canceled. However, using the knowledge of tajweed, the law of fardu 'ain or it could be called compulsory. It should be noted when reading the Qur'an regarding its rules or regulations, because if there is an error in reading it can cause sin. So everyone needs to use the knowledge of 
recitation so that they can read tartil. In the sense of tartil, it is slowly, regularly, enhances the reading, and tries to live up to its meaning. This cannot be done without understanding the procedure for reading the Qur'an in recitation. A person who learns the science of recitation will get several benefits, namely that he will avoid mistakes in reading the verses of the Qur'an, avoid verbal stuttering when reading the verses of the Qur'an. Unlike people who are already stuttering from birth, they will get two rewards at the same time even if they read haltingly. For those who sincerely study the science of tajwid to read the Qur'an with the aim of being given fluency when reading, then that person is likened to reading with noble angels or with as-safarah, al -ugaam, al-bararah and is judged as worship. which has been promised by Allah SWT.

\section{Tahfidz Qur'an Learning Method The}

The word method comes from the Greek language, namely methodos which means a way or towards a path. The method itself is an activity that is directly related to a systematic way of working in understanding the object and subject in research, used as a way to find accountable answers. There are so many people who memorize the Qur'an independently by not using a method, different from that in the Tahfidzul Qur'an educational institution which requires its students to use a predetermined method, but besides that, the results received are not satisfactory.

Now, there are many memorizers of the Al-Qur'an who have created guidebooks that can be used by candidates for hafidz and hafidzah which can make it easier to memorize the Qur'an. This guidebook was made by adjusting their experience when memorizing first, and they deliberately recorded it so that it was used as a guide and reference by the students. But behind the methods he compiled, not all students can use the methods that have been provided and recorded because each student has his own abilities according to his thinking power. The most effective way to speed up time in memorizing the Qur'an. First, do it by reading the verse you will memorize 20 times. For example, the first verse is read 20 times, the second verse is read 20 times, the third verse is read 20 times, the fourth verse is read 20 times. After that the first to the fourth verses are combined and then read 20 times, and so on until it is finished up to 30 juz. In memorizing students are not allowed to memorize more than one-eighth of a day so as not to burden the students during muroja'ah and keep memorizing them. Second, if we want to add more memorization on the next day, then all 
we have to do is repeat the memorization from yesterday so that the memorization will remain strong in the memory. Then just add to the memorization again with the new verse memorized and repeated 20 times as well.

There are several rules and provisions for memorizing the Qur'an. First, during the memorization process, you have to go through a chaplain who can correct your reading if there is a reading that is wrong. Second, in a day memorizing the Koran as much as two pages. One page is memorized after dawn and another page is memorized after Asr or after sunset. God willing, this way can make us memorize the Qur'an in about one year. If the memorizer wants to increase his memorizing capacity every day, it will be difficult for him to keep and solidify his memorization. So that they become weak and many are forgotten. Third, when memorizing the Qur'an one should use one manuscript, this is intended to make it easier in the memorization process and easier to memorize each verse and from the beginning to the last verse on each page. Madrasah Tsanawiyah Islamiyah Blingoh in the learning process of Tahfidzul Qur'an, many methods are used, among others, namely binNadhar, talaqqi, tahfidz, and muroja'ah.

The bin-Nadhar method is a method of memorizing the Al-Qur'an which is done by reading carefully as well as looking at the Mushaf and repeating several times the verses of the Qur'an that you want to memorize. And what is meant by the talaqqi method is to learn by directly paying attention to the words of the ustadz guide by dealing directly with him. This is so that we know and follow the lips and how to read which is good, correct and tartil in reciting rote. This talaqqi method has been exemplified for the first time by the Prophet Muhammad. But until now this method is still valid and is still used by many people, especially those who live in Egypt and Saudi Arabia. The tahfidz method is a method that is carried out by using memorization of the verses of the Qur'an that have been read little by little. Finally, the muroja'ah method, the muroja'ah method is a method that is done by memorizing the memorization that has been submitted to the ustadz supervisor. In language, muroja'ah is a mashdar form of the word roja'a, yarji'u which means to return, while according to terminology it means to recall or repeat what has been memorized. Muroja'ah is also referred to as the periodic repetition method. Muroja'ah is repeating a memorization that has been memorized by keeping what has been memorized not forgotten, which means the memorization that has been deposited to the ustadz mentor who originally memorized it 
smoothly, sometimes there is forgetfulness and some are missing altogether. Therefore, the muroja'ah method was held which had been deposited with the ustadz mentor.

The hafidz and hafidzah are obliged to maintain their memorization, understand them and practice the verses of the Qur'an. Because memorizing the Koran is a big responsibility to become a hafidz-hafidzah that he carries. In this case it is not easy, this has very heavy consequences for hafidz and hafidzah. Because if a hafidz and hafidzah can't remember and keep memorizing, then he will get a sin.

\section{Factors that influence during the process of learning Tahfidz Qur'an.}

Such as memorizing and remembering school lessons, when memorizing the Qur'an there are also many obstacles and obstacles that can complicate the memorization process. Basically, the factors that can influence the process of Tahfidzul Qur'an activities are divided into two parts, namely inhibiting factors and supporting factors.

1) Inhibiting factors in carrying out the process of Tahfidz Qur'an activities are:

a) Lack of talent and interest. The lack of talent and interest when memorizing the Qur'an is one of the most inhibiting factors. Because someone will be too lazy to follow a series of Tahfidzul Qur'an learning processes.

b) Lack of self-motivation. Lack of motivation from those closest to you as well as motivation from yourself can result in a lack of enthusiasm for doing something. Self-motivation is very important because motivation that builds from yourself plays a very important role in the learning process as well as in memorizing. With motivation, someone will be more enthusiastic and more persistent and motivation will make one's learning results get the maximum results. Because motivation has the function of encouraging someone to do something so that something that is desired can be achieved.

c) Many sins and commits immorality. When you want to memorize the Qur'an, one needs to improve one's morals both to Allah and to fellow creatures of Allah, namely being good to both parents, good to friends, 
good to teachers, good to oneself and even to other God's creatures. Staying away from immorality is very important because knowledge is a light or immorality while immorality is darkness, so that someone who acts immoral will extinguish the light of knowledge that is in him. ${ }^{1}$ Among the immoralities that can thwart the concentration of memorization are such as being arrogant or arrogant, riya 'or wanting to be praised by others, reluctance to gather or associate with society, lying, breaking ties of brotherhood and breaking ties of friendship and other heart diseases. So when you want to memorize the Qur'an one needs to be careful and take care of one's attitude, behavior and heart. Because if someone memorizes the Al-Qur'an but still commits immoral acts, his efforts when memorizing the Qur'an will be in vain. It is very likely that the person is not successful in memorizing the Qur'an.problems are

d) Frequently, the health is affected. Health is one of several factors that are very important in the process of Tahfidzul Qur'an, because when one's health is disturbed it can become an obstacle in one's progress. When someone has difficulty memorizing the Qur'an because there is a physical disturbance due to illness, what must be done is to make an effort. Effort is used as an effort to get to a situation so that it is better than the previous state. Muslims are strongly encouraged to make every effort to do everything. The purpose of this endeavor is an effort to seek treatment so that the body is healthy quickly and can return to normal activities.

e) Low level of intelligence. Everyone must have intelligence which includes intellectual question, emotional question and spiritual question. One of the important factors in the process of Tahfidzul Qur'an activities is the Intellectual Question. However, the intelligence or intelligence of a person depends on how they try to hone it.

f) The age factor is old. At an older age, it usually causes less effectiveness in the learning process, especially in memorizing the Qur'an. Because at an unproductive age a person's memory will decline, memorizing the

${ }^{1}$ Endah Kurniati, Oxygen To Live, (Yogyakarta: Deepublish, 2019), hal.18 
Qur'an requires someone who can have a strong memory. If you have a weak memory, it can hinder one's success in the process of memorizing someone.

2) Supporting factors in carrying out the process of Tahfidz Qur'an activities

a) careful preparation. In memorizing the Qur'an, there is one important condition that must be present in a person, namely mature self-readiness. Because mature readiness is closely related to one's interests. Because interest is one of the first assets to prepare yourself carefully in the process of Tahfidzul Qur'an.

b) Stimulus and motivation. Stimulus and motivation must always be nurtured in a person. Because when memorizing the Koran, one is required to be serious, so there is willpower without knowing despair and feeling bored. Therefore motivation and stimulus must be considered.

c) Age factor. In memorizing the Qur'an there is no age limit, but it must also be considered regarding the effective age. Because memorizing the Qur'an at a productive age is better, which is around the age of 5-20 years than memorizing at the age of 30-40 years. Memorizing the Al-Qur'an must also be taken into account regarding age because it is related to a person's memory. There is a saying about the age of learning, namely "Learning as a child is like carving on a rock, while learning as an adult is like carving on water." This suggests that learning at a young age is more effective because the memory and thinking power are still good so they are easy to make an impression on the memory. Unlike learning at an adult age, the mind is divided, so it will be more difficult to remember what has been learned or memorized.

d) Time setting. In memorizing the Al-Qur'an, one must be clever in utilizing and appreciating time as well as possible. Therefore, as a candidate for hafidz and hafidzah, it is very important in choosing the time to use between when he is doing an activity and when is a good time to memorize the Qur'an. All times can be used to memorize the Al-Qur'an, but there are several times that are quite effective which are easy to 
memorize the Qur'an, namely early morning or one third of the night, after dawn until sunrise, after the five daily prayers, and the time between sunset and isha'.

e) Potential memory and intelligence. Memory and intelligence factors are psychological factors. Someone who has a high memory and intelligence will be faster and easier in the process of memorizing the Qur'an than someone who has a memory and intelligence that is below average.

f) Place to memorize: the condition of a place that is poorly lit, shabby and there is a lot of noise pollution can disturb the concentration of someone who is memorizing, different if someone studies in a place that is sufficiently lit, clean, calm and comfortable, they will be easier to memorize.

\section{Conclusion}

It is very important in memorizing the Qur'an to cultivate in the heart sincere intentions because of Allah. Second, when you want to memorize Al-Qur'an you must seek the pleasure of Allah SWT and seek happiness in the hereafter. In the Tahfidz learning process, the ustadz supervisor does not only see from the side of memory but from the side of the reading also about the letter makhorijul and recitation.

Some of the methods used in memorizing the Qur'an, among others, bin-Nadzar, is a method of memorizing the Qur'an which is done by reading it carefully while looking at the mushaf and repeating the verses to be memorized. The talaqqi method is a method that is carried out by keeping the memorization that has just been memorized to the ustadz supervisor. The tahfidz method is a method that is done by memorizing the verses of the Qur'an that have been read little by little. The muroja'ah method is a method that is carried out by repeating the memorization that has been told to the mentor ustadz. The hafidz and hafidzah are obliged to keep memorizing it, understand it.

As a memorizer of the Koran, hafidz and hafidzah must bear a heavy responsibility. During the learning process there are several inhibiting factors in carrying out the Tahfidzul Qur'an learning process, namely as follows: lack of interest and talent, lack of motivation in oneself, commit lots of sins and immorality, low intelligence levels of children, frequent health problems and age that is not productive or old. While the supporting factors are careful 
preparation, motivation and stimulus, age factor, timing, potential for memory and intelligence as well as a place to memorize.

\section{Suggestion}

Thus the article that we have complied, so that it can be useful for readers and be able to provide knowledge about the Tahfidz Qur'an learning method. So that readers are more enthusiastict in memorizing the Qur'an.

\section{References}

Al-Qasim, Syaikh Abdul Muhsin. Cara Menghafal Al-Qur'an dan Matan Ilmiah. Jawa Tengah: Mufid, 2010.

Al-Qudhat, Muhammad Isham Muflih. Panduan Lengkap Tajwid. Jakarta: Turos Pustaka, 2015.

Aprianti. Metode Pembelajaran Tahfidz Qur'a di Pondok Pesantren Tahfidz Al-Qur'an Imam Asy-Syafi'i Desa Bandung Marga Kecamatan Bermani Ulu Raya, Bengkulu : Fakultas Tarbiyah, Sekolah Tinggi Agama Islam Negeri Curug, 2016.

Arief, Armai. Pengantar Ilmu dan Metodologi Pendidikan Islam, Jakarta: Ciputat Press, 2012. Asteria, Prima Vidya. Mengembangkan Kecerdasan Spiritual Anak Melalui Pembelajaran Membaca Sastra. Malang: Universitas Brawijaya Press, 2014.

Chairani, Lisya dan M.A Subandi. Psikologi Santri Penghafal Al-Qur'an. Yogyakarta: Pustaka Pelajar, 2010.

Efendi, Jonaedi and Johnny Ibrahim. Metode Penelitian Hukum Normatif dan Empiris. Depok: Prenadamedia Group, 2016.

El-Mahfani, Khailurrahman. Belajar Cepat Ilmu Tajwid. Jakarta Selatan: PT Wahyu Media, 2014.

Fathurrohman, M. Mas'udi. Cara Mudah Menghafal Al-Qur'an dalam 1 Tahun. Yogyakarta: Elmatera, 2012.

Hamid, Abdul. Pengantar Studi Al-Qur'an. Jakarta : Prenadamedia Group, 2016.

Kurniati, Endah Kurniati. Oxygen To Live. Yogyakarta: Deepublish, 2019.

Ma'shun, Ahmad. 2016. Pembelajaran Tahfidz Al-Qur'an di Pondok Pesantren Tahfidzul Qur'an Darul Quro Sidareja, Purwokerto: Fakultas Tarbiyah dan Ilmu Keguruan Program Studi Pendidikan Agama Islam. 
Mubarok, Imam. Buku Pintar Hafalan Bacaan Sholat Plus Do'a Harian. Yogyakarta: Laksana, 2019.

Parmono, Wahyono Hadi and Ismunandar. 17 Tuntunan Hidup Muslim. Yogyakarta: Deepublish, 2004.

Qomariyah, Nurul and Mohammad Irsyad,. Metode Cepat dan Mudah agar Anak Hafal. Yogyakarta: Semesta Hikmah, 2016.

Qori, M. Taqiyul Islam. Cara Mudah Menghafal Al-Qur'an. Jakarta: Gema Insani, 1998.

Rahman, Abd, Abd Ghani dan Mohd Aderi bin Che Noh, "Implementation of Tajweed Curriculum in Pondok Schools at Perak", International Journal of Advanced Science and Technology, vol. 29, No.7, 2020.

Riyanto, Theo. Memotivasi Diri Langkah Menuju Sukses. Yogyakarta: Kanisius, 2010.

Rusyd, Raisya Maula Ibnu. Panduan Praktis Dan Lengkap Tahsin, Tajwid, Tahfidz untuk Pemula,. Yogyakarta: Laksana, 2019.

Tanto, Eko Aris, Syarif Hidayatullah dan Ike Kusdyah Rachmawati, Taud Tabungan Akhirat: Perspektif “Kuttab Rumah Qur'an”. Jawa Timur: Uwais Inspirasi Indonesia, 2019. 
Ummi Rohmawati, Ashif Az Zafi

42 | IQ (Ilmu Al-qur'an): Jurnal Pendidikan Islam | Volume 4 No.01 2021, 29-42 